УДК 338.439.4

doi 10.18522/2687-0770-2021-1-95-100

\title{
FROM PRIORITY TO DIVERSITY: PROSPECT OF EDUCATIONAL COOPERATION FOR CHINESE AND RUSSIAN REGIONAL UNIVERSITIES
}

\author{
(C) 2021 Huang Zhidong ${ }^{a}$ \\ ${ }^{a}$ Southern Federal University, Rostov-on-Don, Russia \\ ОТ ПРИОРИТЕТА К РАЗНООБРАЗИЮ: \\ ПЕРСПЕКТИВЫ ОБРАЗОВАТЕЛЬНОГО СОТРУДНИЧЕСТВА \\ КИТАЙСКИХ И РОССИЙСКИХ РЕГИОНАЛЬНЫХ УНИВЕРСИТЕТОВ
}

\author{
Хуан Чжсидун ${ }^{a}$ \\ ${ }^{a}$ Южный федеральный университет, Ростов-на-Дону, Россия
}

Huang Zhidong -

Postgraduate,

Department of Innovation

and International Management,

Southern Federal University,

Gorkogo St., 88, Rostov-on-Don, 344002, Russia.

E-mail: chuan@sfedu.ru

\author{
Хуан Чжидун - \\ аспирант, \\ кафедра инновачионного \\ и международного менеджмента, \\ Южный федеральный университет, \\ ул. Горького, 88, г. Ростов-на-Дону, \\ 344002, Россия. \\ E-mail: chuan@sfedu.ru
}

Internationalization of higher education is a trend of future education. Chinese-Russian higher education cooperation has increased rapidly. The regional education cooperation between the China and Russia should be enhanced \& promot$e d$. The author's results of the questionnaire from the Chinese students of the Southern Federal University, in Rostov-onDon, show that the satisfaction of education of Chinese students is very high, which will bring positive choice preference to regional institutes for bilateral education cooperation.

The survey shows, the international students' alternative for further education in Russia tends to diversify instead of priority. Based on the reality that the analysis reveals, regional universities of the Russian Federation should highlight its feasibility of international regional education cooperation, and create more positive and pragmatic strategies for realistic vulnerabilities. The goal is to improve the attractiveness of Russian education programs to foreign citizens, improve their conditions of stay while studying in Russia, and enhance the visibility and status of Russian education brands in the international education market.

Keywords: Chinese-Russian regional education cooperation, priority, diversity, regional universities, survey analysis, international education market, visibility and status of Russian education brands.

Интернациионализация высшего образования является тенденџиией образования будущего. Китайскороссийское сотрудничество в сфере высшего образования быстро расширяется. Региональное сотрудничество в области образования между Китаем и Россией следует расширять и развивать. Результать авторского анкетирования китайских студентов Южного федерального университета в Ростове-на-Дону показывают, что удовлетворенность китайских студентов обучением очень высока, что задает региональным институтам положительный вектор для двустороннего сотрудничества в области образования.

Опрос показывает, что альтернатива дальнейшему образованию со стороны иностранных студентов имеет тенденцию к диверсификации, а не приоритету. Исходя из реальности, которую демонстрирует анализ, региональные университеть Российской Федерации должны подтвердить иелесообразность международного регионального сотрудничества в области образования, а также разработать более позитивные и прагматичные стратегии для ликвидации проблемных зон. Цель управления - повысить привлекательность российских образовательных программ для иностранных граждан, улучшить условия их пребывания во время обучения в России, а также повысить узнаваемость и статус российских образовательных брендов на международном рынке образовательных услуг. 
Ключевые слова: китайско-российское региональное сотрудничество в области образования, приоритет, разнообразие, региональные университеты, анализ опроса, международный рынок образования, узнаваемость и статус российских образовательных брендов.

\section{Introduction}

In the last two decades, Russia Federation and People's Republic of China strengthen economic ties and enhance cultural exchanges which promotes regional education cooperation. Personal satisfaction by evaluating of academic quality and infrastructure will affect choice preference when international students choose destination abroad. In order to identify the satisfaction from international students, based on evaluation of academic quality and infrastructure, a survey is implemented in 2019. This paper is the second part of the survey ${ }^{1}$.

In 2018 the bilateral trade between Russia and China amounts to $\$ 107$ billion. In terms of trade scale and structure, according to the statistics of the General Administration of Customs of China, the bilateral trade between China and Russia increased by $27.1 \%$ in 2018, ranking first among China's major trading partners. China continues to maintain its position as Russia's largest trading partner, and Russia is China's tenth largest trading partner [1].

Russia's unique culture has attracted more Chinese tourists. According to the information released during the fourth China Russia Mongolia Tourism Ministers' Meeting, in 2018, 2,414 million Russian citizens visited China, an increase of $3 \%$ year on year. 2,037 million Chinese citizens visited Russia, up $21.3 \%$ year on year [2].

Mutual economic interconnection and cultural attraction between China and Russia have created favorable conditions for expanding Sino-Russian educational cooperation. Regional education cooperation provides more opportunities to Chinese students to get better higher education in Russia. In 2019, there were 24,226 Chinese students studying at Russian universities, an increase of $23.6 \%$ compared with 2018 [3].

Two decades ago, Chinese students took priority to study at universities located in Moscow or St. Petersburg, nowadays more than three hundred thousand Chinese students study in five hundred institutions located in eighty-five cities of Russia [4]. With the rapidly increase of the number of Chinese students, more and more Russian regional universities have taken part in regional education co-

\footnotetext{
1 Часть 2. Продолжение статьи: Huang Zhidong. Factors Influencing Chinese Student Preference Bias Towards Russian Regional Universities // Изв. вузов. Сев.-Кавк. регион. Обществ. науки. 2020. № 1. С. 89-94.
}

operation. Consequently, regional education cooperation has been a trend from priority to diversity, which will make a great influence on the regional education cooperation between the Russian Federation and PRC.

For Russian regional universities, it is vital to get more international student market share from the trend of diversity to expand the scope of academic influence globally. In regard to regional universities, there is a need to research, what determine the possibility to attract more Chinese students and strengthen the regional education cooperation when they choose a regional university as their destination?

\section{Methodology and Sample}

Sociological research on this issue is implemented by questionnaires among one hundred and twenty Chinese students studying at Southern Federal University of Russia. The survey is comprised of twenty-three questionnaires; eleven of them are taken as samples for the sequel of another paper. The samples make it possible to trace the satisfaction of international students studying at a regional university in Russia Federation.

The aim of the second part of the survey is to identify the satisfaction of international students, based on personal evaluation of academic quality and infrastructure, after international students have studied at a regional university of the Russian Federation for three months. The analysis makes it possible to offer constructive advice to the Russian regional institutions for the policy-making of regional education cooperation.

\section{Topics of the survey}

Questionnaires are divided into several topics, such as satisfaction about courses and infrastructure, willingness to get further study at a regional university of Russia.

The research is based on these topics, focusing on personal satisfaction with educational quality, campus living and study which represent objective opinion about the regional education cooperation.

\section{Participants}

In order to compare the results of the survey, different participants have been chosen as far as 
possible: undergraduate, graduate, postgraduate. There are one hundred and twenty international students from China participating the survey, all of them are studying at Southern Federal University of Russia.

\section{Response and representativeness}

Considering the background of participants and dimensions of the questionnaires, we insist that the participation in the survey is anonymous and voluntary. The questions should be completed; one hundred and twenty completed responses have been taken back.

\section{Analysis and discussion}

According to the statistics, table 1 shows that eighty-two students, making up $68.3 \%$, have inquired about the location and transportation of the university before they go to Russia which indicates that logistics has a powerful impact on regional education cooperation; and $41.7 \%$ of the students have contacted other students who have already studied in this university, which shows that impression from registered students will affect new comers' choice preference.

Table 1

Preparation students have made before they come to South Federal University

/ Подготовительные действия студентов, предпринятые перед поступлением

в Южный федеральный университет

\begin{tabular}{|l|c|}
\hline \multicolumn{1}{|c|}{ Preparation } & Percentage \\
\hline To check accommodation information & 22.5 \\
\hline $\begin{array}{l}\text { To inquire about the location and transpor- } \\
\text { tation of the university }\end{array}$ & 68.3 \\
\hline $\begin{array}{l}\text { To access to information about Russian } \\
\text { culture }\end{array}$ & 37.5 \\
\hline $\begin{array}{l}\text { To make a budget for studying and living } \\
\text { in Russia }\end{array}$ & 43.3 \\
\hline To enquire Russian banking system & 3.3 \\
\hline $\begin{array}{l}\text { To contact students who have already stud- } \\
\text { ied in this university }\end{array}$ & 41.7 \\
\hline $\begin{array}{l}\text { To enquire the information on Russian life } \\
\text { insurance }\end{array}$ & 5.8 \\
\hline $\begin{array}{l}\text { To inquire about telephone and Internet } \\
\text { information of Russia }\end{array}$ & 11.7 \\
\hline To learn Russian & 58.3 \\
\hline
\end{tabular}

For the academic quality, table 2 reveals that $80.8 \%$ international students give positive response, only $19.2 \%$ give negative response, which shows that international students are very satisfied with the quality of Russian higher education.

Table 2

The academic quality students have received from the university / Академическая успеваемость студентов в университете

\begin{tabular}{|l|c|}
\hline \multicolumn{1}{|c|}{ Quality } & Percentage \\
\hline Very good & 31.7 \\
\hline Good & 49.1 \\
\hline Very poor & 19.2 \\
\hline Poor & 0 \\
\hline
\end{tabular}

For the satisfaction of accommodation, table 3 presents that $75 \%$ of them are quite content, $25 \%$ of respondents are disappointed. For the impression of the university life in Russia, table 4 shows that about $70 \%$ international students give positive response.

Table 3

Suitability of the accommodation / Оценка пригодности жилья

\begin{tabular}{|l|c|}
\hline \multicolumn{1}{|c|}{ Suitability } & Percentage \\
\hline Very suitable & 30.0 \\
\hline Suitable & 45.0 \\
\hline Not suitable & 20.8 \\
\hline Not suitable at all & 4.2 \\
\hline
\end{tabular}

Table 4

Impression of the university life in Russia / Впечатление от университетской жизни в России

\begin{tabular}{|l|c|}
\hline \multicolumn{1}{|c|}{ Impression } & Percentage \\
\hline Very good & 26.7 \\
\hline Good & 41.7 \\
\hline Poor & 31.6 \\
\hline Very poor & 0 \\
\hline
\end{tabular}

Based on the satisfaction, table 5 tells us that more than $90 \%$ international students will recommend Russia regional universities as study destination to other Chinese students.

Table 5

Willingness to recommend Russia regional university as a study destination to other students / Готовность рекомендовать российский региональный университет в качестве места обучения другим студентам

\begin{tabular}{|l|c|}
\hline \multicolumn{1}{|c|}{ Willingness } & Percentage \\
\hline Definitely yes & 19.2 \\
\hline Probably yes & 71.7 \\
\hline Probably no & 9.1 \\
\hline Definitely no & 0 \\
\hline
\end{tabular}


Although international students satisfied with academic quality and the accommodation, they have encountered various difficulties in life and study. It can be seen from table 6 , a multiple-choice question that 28.3\% international students have taken part in Russia fraternity, only $13.3 \%$ have taken part in university scientific projects and grants, $22.5 \%$ have taken part in university sport/culture projects, and $55.0 \%$ have not taken part in any university activities.

Participation in out-classes activity of the university / Участие во внеучебной деятельности вуза

\begin{tabular}{|l|c|}
\hline \multicolumn{1}{|c|}{ Participation } & Percentage \\
\hline Taking part in Russia fraternity & 28.3 \\
\hline $\begin{array}{l}\text { Taking part in university scien- } \\
\text { tific projects and grants }\end{array}$ & 13.3 \\
\hline $\begin{array}{l}\text { Taking part in university } \\
\text { sport/culture projects }\end{array}$ & 22.5 \\
\hline Other & 55.0 \\
\hline
\end{tabular}

Table 7, a multiple-choice question, presents the difficult things which have negative influence on study or living in Russia for international students from China. Living and cultural difference accounts for $50,8 \%$, language difficulty $58,3 \%$, and infrastructural conditions $37,5 \%$ respectively.

Table 7

Difficult things which have negative influence on your study or living in Russia / Сложности, оказывающие негативное влияние на обучение или жизнь в России

\begin{tabular}{|l|c|}
\hline \multicolumn{1}{|c|}{ Difficult things } & Percentage \\
\hline Living and cultural difference & 50.8 \\
\hline Teaching standards and methodology & 26.7 \\
\hline Language difficulty & 58.3 \\
\hline Infrastructural conditions & 37.5 \\
\hline Administrative rules & 19.2 \\
\hline Other & 9.2 \\
\hline
\end{tabular}

Table 8 shows that $25.8 \%$ international students from China have willingness to continue education at a regional university of Russia, $21.7 \%$ will move to a capital university of Russia after graduation, and $31.7 \%$ will return to China.

Table 9 reveals the employment preference of international students, that $21.7 \%$ international students want go to an academic institute, $49.1 \%$ want to work as an employee in a company, and $21.7 \%$ want to start up business by themselves.
Table 8

Willingness to continue education in Russia regional university / Готовность продолжить обучение в российском региональном вузе

\begin{tabular}{|l|c|}
\hline \multicolumn{1}{|c|}{ Willingness } & Percentage \\
\hline $\begin{array}{l}\text { To continue education at a regional uni- } \\
\text { versity of Russia }\end{array}$ & 25.8 \\
\hline To move to the capital university of Russia & 21.7 \\
\hline To continue study in the other country & 8.3 \\
\hline To return home and work/study & 31.7 \\
\hline Other & 12.5 \\
\hline
\end{tabular}

Table 9

The way to apply what you have learned in Russia to practice after your graduation / Пути применения навыков на практике после окончания учебы в России

\begin{tabular}{|l|c|}
\hline \multicolumn{1}{|c|}{ Ways } & Percentage \\
\hline To go to an academic institute & 21.7 \\
\hline To work as an employee in a company & 49.1 \\
\hline To work as a civil servant in China & 1.7 \\
\hline To start up my business & 21.7 \\
\hline Other & 5.8 \\
\hline
\end{tabular}

Table 10 includes the answers to a multiplechoice question. International students are required to choose some criteria they have taken into consideration for the selection of a regional university in Russia. It can be seen from the survey, $55 \%$ choose world university rankings of the regional university, $27.5 \%$ choose the quality of teachers/tutors of the regional university. For international students, to get better education is the most important factor to make the decision to study abroad in Russian regional institutions.

Table 10

Criteria students take into consideration for the selection of regional university in Russia / Критерии, которые принимаются во внимание студентами при выборе регионального вуза в России

\begin{tabular}{|l|c|}
\hline \multicolumn{1}{|c|}{ Criteria } & Percentage \\
\hline $\begin{array}{l}\text { World university rankings of the re- } \\
\text { gional university }\end{array}$ & 55.0 \\
\hline Quality of teachers/tutors & 27.5 \\
\hline Friends' opinion & 23.3 \\
\hline Parents or relatives' opinion & 21.5 \\
\hline Other & 27.5 \\
\hline
\end{tabular}

Table 11 shows the result of another multiplechoice question about the factors which affect the 
willingness of Chinese international students to choose a regional university in Russia. It can be seen from the survey, living and accommodation cost makes up $37.5 \%$, more opportunities for further education make up $35.8 \%$. Therefore, study cost and educational opportunities are the most important reasons for Chinese students to choose a regional university in Russia.

Table 11

Reasons for your decision to study in Russia regional university / Причины решения учиться в российском региональном университете

\begin{tabular}{|l|c|}
\hline \multicolumn{1}{|c|}{ Reasons } & Percentage \\
\hline Living and accommodation cost & 37.5 \\
\hline Suitable class quality for your field of study & 25.0 \\
\hline Strong faculty of the university & 23.3 \\
\hline More opportunities for further education & 35.8 \\
\hline Other & 27.1 \\
\hline
\end{tabular}

\section{Conclusion}

In recent years, great changes have taken place in the world pattern, and the internationalization of higher education is the general trend. The internationalization of tertiary education has taken various forms. Countries compete to attract larger numbers of foreign students who are the source of valuable income and reputation for host universities and countries [5].

China and Russia are each other's largest neighbor, with increasingly close ties in the economic, political and social fields; the relationship between the two countries has risen to a comprehensive strategic cooperative partnership. It is urgent to enhance the cultural and educational cooperation, especially in the field of higher education cooperation for regional universities.

Firstly, it is valuable to enhance the attraction and promote the regional education cooperation. The survey reveals that the satisfaction from Chinese students is very high, which will bring positive choice preference to regional institutes for bilateral education cooperation. For Chinese students, on the one hand, studying in Russia has its own attraction in terms of satisfaction with accommodation and academic quality. On the other hand, Russia has its traditional advantageous majors, and the quality of teaching is guaranteed by the system. Therefore, integrating the core value of education cooperation will make it sustainable and stable.
Secondly, it is urgent to solve the problems related to regional education cooperation which will reduce the enthusiasm and willingness of choosing regional institutes. Chinese students studying in Russia generally will face problems such as low level of language, inconvenient logistics and transportation, great cultural differences and different teaching methods between the two countries, which have a certain impact on the study and life of students studying in Russia. On the premise of respecting the educational and cultural differences between China and Russia, we should find more effective solutions to the problems which affect the enthusiasm and willingness of learning in Russia.

Thirdly, both China and Russia have entered a new period of development which provides great opportunities for regional education cooperation. On the basis of existing cooperation, there is great potential for regional education cooperation. Therefore, it is needed to further expand the level of exchanges and improve the scale of educational cooperation. The prospect of regional education cooperation is very broad, Russian regional institutions should consider the factors fully when making policies to enhance regional education cooperation.

Internationalization of higher education is a trend of future education. With the advancement of global economic integration, the degree of regional economic integration has a profound impact on the regional education cooperation. Meanwhile, more and more Russian regional institutions have taken part in international education to seize the international student market which has been subdivided.

From the survey analysis, the alternative from international students tends to diversity instead of priority. Based on the reality that the analysis reveals, regional universities should highlight its feasibility of regional education cooperation, and create more positive and pragmatic strategies for realistic vulnerabilities. The goal is to improve the attractiveness of Russian education programs to foreign citizens, improve their conditions of stay while studying in Russia, and enhance the visibility and status of Russian education brands in the international education market [6].

\section{References}

1. General Administration of Customs P.R. China. Available at: http://www.customs.gov.cn/ (accessed October 20, 2020).

2. Available at: http:// sputniknews.cn/russia_china_relations/201906261028852762/ (accessed October 20, 2020). 
3. Available at: https:// baijiahao.baidu.com/ $\mathrm{s} ? \mathrm{id}=1660850769102085337 \& \mathrm{wfr}=$ spider $\&$ for $=\mathrm{pc} \quad(\mathrm{ac}-$ cessed October 20, 2020).

4. China Daily. 2019. Third June. Available at: http://ru.people.com.cn/n1/2019/0604/c408039-

31117973.html (accessed October 20, 2020).

5. UNESCO: Global Education Monitoring Report 2019.

6. About the priority project "Export of education". (in Russian).

\section{Литература}

1. General Administration of Customs P.R. China. URL: http://www.customs.gov.cn/ (дата обращения: 20.10.2020).
2. URL: http:// sputniknews.cn/ russia_china_relations/ 201906261028852762/ (дата обращения: 20.10.2020).

3. URL: https:// baijiahao.baidu.com/ s?id=166085 $0769102085337 \& w f r=s p i d e r \&$ for=pc (дата обращения: 20.10.2020).

4. China Daily. 2019. Third June. URL: http://ru.people.com.cn/n1/2019/0604/c408039-

31117973.html (дата обращения: 20.10.2020).

5. UNESCO: Global Education Monitoring Report 2019.

6. О приоритетном проекте «Экспорт образования». 